\title{
FAKTOR-FAKTOR YANG BERHUBUNGAN DENGAN PEMBERIAN IMUNISASI HEPATITIS B-0 PADA IBU YANG MEMILIKI BAYI DI PUSKESMAS BONAI DARUSSALAM PASIR PANGARAIAN KABUPATEN ROKAN HULU
}

\author{
Yulrina Ardhiyanti
}

STIKes Hang Tuah Pekanbaru

Email: rien.ardhi@yahoo.co.id

\section{ABSTRACT}

Universal Child Immunization (UCI) target of Hepatitis B immunization must be achieved $80 \%$ in national, province, regency or even a village. PD3I surveillance data shows scope of HB-0 (0-7 days) immunization in Riau, from 2007-2013 still below national targets. Based on information from paramedic in Bonai Darussalam Health Care, low immunization coverage because some people do not know the benefits and afraid if their infants get immunization an earlier time. This study aims to understand related factors of provision Hepatitis B-0 immunization in Bonai Darussalam Health Care, Pasir Pangaraian, Rokan Hulu in 2016. Quantitative research methods and research design used cross sectional. The study was conducted in Bonai Darussalam Health Care, Pasir Pengaraian in February 2016 using questionnaires with 50 people total respondents. Sampling was taken by accidental sampling technique. The results show that 42 people (84\%) did not give HB0 immunization. Test results chi-square statistic show connection between respondent's knowledge with HB-O immunization $O R=2.0$ (95\% CI 1.22 to 3.26), futhermore, there is a correlation relationship between the respondent's attitudes with immunization $H B-0 O R=21.8$ (95\% CI 1.19 to 2.72), and the relationship between the respondent's educational with HB-0 immunization $O R=1.8$ (95\% CI 1.20 to 2.95). A recommendation for paramedic in Bonai Darussalam Health Care is to improve their performance in terms of providing information to mothers who have babies, private midwives and herbalists in the area and it hopes that mother could be motivated to provide immunization $H B-0$.

Keywords : Knowledge, Attitudes, Educational, Provision Hepatitis B-0 Immunization

\section{PENDAHULUAN}

Imunisasi adalah suatu cara untuk meningkatkan kekebalan seseorang secara aktif terhadap suatu penyakit, sehingga bila kelak ia terpapar dengan penyakit tersebut tidak akan sakit atau sakit ringan. Upaya pelayanan imunisasi dilakukan melalui kegiatan imunisasi rutin dan tambahan dengan tujuan untuk menurunkan angka kesakitan dan kematian akibat Penyakit-penyakit yang Dapat Dicegah Dengan Imunisasi (PD3I). Penyakit menular yang saat ini masuk kedalam program imunisasi adalah Tuberkulosis, Difteri, Pertusis, Polio, Campak, Tetanus dan Hepatitis B (Depkes 2005).

Hepatitis B adalah penyakit infeksi yang menyerang hati yang disebabkan oleh virus hepatitis B yang merusak hati dengan masa inkubasi 14-160 hari. Penyebaran penyakit terjadi melalui darah dan produknya, melalui suntikan yang tidak aman, transfusi darah, proses persalinan atau melalui hubungan seksual. Dengan melihat masa inkubasi tersebut maka pemberian imunisasi secara aktif diberikan pada waktu kurang dari 7 hari (Hidayat \& Pujianto, 2008).

Infeksi penyakit Hepatitis B pada anak seringkali subklinis dan biasanya tidak menimbulkan gejala. Gejala infeksi klinis akut ditandai dengan badan terasa lemah, gangguan perut dan gejala lain seperti flu, urine menjadi kuning, kotoran menjadi pucat. Warna kuning bisa terlihat pula pada mata ataupun kulit. Risiko terjadinya penyakit kronis pada penderita Hepatitis B, jauh lebih besar bila infeksi terjadi mulai dari awal kehidupan dibandingkan dengan infeksi terjadi pada usia dewasa. Infeksi pada masa bayi mempunyai risiko untuk menjadi carrier kronis sebesar 95\% dan menimbulkan chirrhosishepatis (kanker hati) yang dapat menimbulkan kematian (Hidayat, 2008).

Ada tiga cara untuk mencegah penularan infeksi Hepatitis B, yaitu melalui perubahan 
pola hidup, imunisasi pasif, dan imunisasi aktif atau vaksinasi. Imunisasi Hepatitis B diberikan dalam waktu 12 jam setelah lahir, kemudian dilanjutkan pada usia 1-6 bulan dengan interval waktu minimal 4 minggu (Hidayat, 2008). Pemberian vaksin pada minggu pertama kehidupan (0-7 hari) telah berhasil menurunkan perkembangan penyakit Hepatitis B secara signifikan sehingga pemerintah menetapkan dosis pertama diberikan pada usia $0-7$ hari dan dosis berikutnya diberikan dengan interval 4 minggu (1 bulan) (Depkes RI, 2005).

\section{Target UCI (Universal Child} Immunization) untuk sasaran imunisasi Hepatitis B harus mencapai $80 \%$ baik ditingkat nasional, provinsi, kabupaten bahkan di setiap desa (Ranuh, 2008). Berdasarkan bulletin data surveilans PD3I, cakupan Imunisasi HB-0 (0-7 hari) di Riau dari tahun 2007-2013 mengalami grafik yang signifikan. Pada tahun 2007 (71,8\%), 2008 (75,1\%), 2009 (56,9\%), 2010 (56,3\%), $2011(68,2 \%), 2012(68 \%)$, dan tahun 2013 (68,2\%) (Depkes, 2013).

Data yang diperoleh dari Dinas Kesehatan Kabupaten Rokan Hulu bulan Mei 2015, dari 21 puskesmas diperoleh data cakupan Imunisasi HB-0 yang terendah terdapat di Puskesmas Bonai Darussalam yaitu 6,3\%. Persentase ini juga terlihat pada 3 bulan sebelumnya. Jumlah cakupan Imunisasi HB-0 pada bulan Februari adalah 11 bayi dari 499 bayi (2,1\%), pada bulan Maret adalah 9 bayi dari 499 bayi (1,7\%) dan pada bulan April adalah 7 bayi dari 499 bayi $(1,4 \%)$. Hal ini berarti masih jauh dibawah terget yang diharapkan.

Berdasarkan informasi yang diberikan oleh tenaga kesehatan di Puskesmas Bonai Darussalam, rendahnya angka cakupan imunisasi HB-0 pada bayi disebabkan karena sebagian masyarakat belum mengetahui manfaat imunisasi Hepatitis B-0 dan mereka merasa takut serta kasihan melihat bayi mereka diberi imunisasi pada waktu dini.

Berdasarkan permasalahan diatas, maka peneliti tertarik untuk melakukan penelitian dengan judul "Faktor-faktor yang Berhubungan dengan Pemberian Imunisasi Hepatitis B-0 pada Ibu yang Memiliki Bayi di Puskesmas Bonai
Darussalam Pasir Pangaraian Kabupaten Rokan Hulu Tahun 2016".

Tujuan dari penelitian ini yaitu untuk mengetahui hubungan pengetahuan ibu dengan pemberian imunisasi Hepatitis B-0 pada ibu yang memiliki bayi di Puskesmas Bonai Darussalam Pasir Pangaraian Kabupaten Rokan Hulu, untuk mengetahui hubungan sikap ibu dengan pemberian imunisasi Hepatitis B-0 pada ibu yang memiliki bayi di Puskesmas Bonai Darussalam Pasir Pangaraian Kabupaten Rokan Hulu, untuk mengetahui hubungan pendidikan ibu dengan pemberian imunisasi Hepatitis B-0 pada ibu yang memiliki bayi di Puskesmas Bonai Darussalam Pasir Pangaraian Kabupaten Rokan Hulu, untuk mengetahui hubungan dukungan keluarga ibu dengan pemberian imunisasi Hepatitis B-0 pada ibu yang memiliki bayi di Puskesmas Bonai Darussalam Pasir Pangaraian Kabupaten Rokan Hulu.

Manfaat dari penelitian ini diharapkan hasil penelitian ini dapat digunakan sebagai masukan bagi tempat pelayanan dalam meningkatkan mutu layanan, khususnya dalam pemberian imunisasi Hepatitis B-0 (0-7 Hari) pada bayi yang berumur $0-12$ bulan.

\section{METODOLOGI PENELITIAN}

Jenis penelitian ini dilakukan menggunakan penelitian kuantitatif dengan pendekatan studi korelasi, desain penelitian yang digunakan adalah cross sectional. Lokasi penelitian dilaksanakan di Puskesmas Bonai Darussalam Pasir Pengaraian Kabupaten Rokan Hulu. Waktu penelitian dilakukan pada tanggal 1-29 Februari 2016. Subyek penelitian adalah ibu yang memiliki bayi usia $0-12$ bulan. Jumlah responden sebanyak 50 orang berdasarkan data kunjungan ibu yang memiliki bayi usia 0-12 bulan di Puskesmas Bonai Darussalam.

Teknik sampling yang digunakan accidental sampling yakni suatu teknik penentuan sampel berdasarkan kebetulan, yaitu siapa saja yang secara kebetulan bertemu dengan peneliti dapat dipakai sebagai sampel, jika dipandang orang yang kebetulan ditemui itu cocok untuk dijadikan sebagai sumber data (Sugiyono, 2011). 


\section{HASIL DAN PEMBAHASAN}

Hasil univariat diperoleh dari faktorfaktor yang berhubungan dengan pemberian imunisasi Hepatitis B-0 yang meliputi : pengetahuan, sikap, pendidikan, dukungan keluarga. Mayoritas responden berpengetahuan kurang $68 \%$, bersikap negatif $64 \%$, berpendidikan rendah $68 \%$, tidak mendapatkan dukungan keluarga $60 \%$ dan $84 \%$ tidak memberikan imunisasi Hepatitis B- 0 pada bayinya.

\section{Tabel 1.}

Distribusi Frekuensi Faktor-faktor yang Berhubungan dengan Pemberian Imunisasi

Hepatitis B- 0 pada Ibu yang Memiliki

Bayi di Puskesmas Bonai Darussalam Kabupaten Rokan Hulu Tahun 2016

\begin{tabular}{lcc}
\hline \multicolumn{1}{c}{ Kategori } & Jumlah & Persentase (\%) \\
\hline Pengetahuan & & \\
Kurang & 34 & 68 \\
Baik & 16 & 32 \\
\hline \multicolumn{1}{c}{ Jumlah } & $\mathbf{5 0}$ & $\mathbf{1 0 0}$ \\
\hline Sikap & & \\
Negatif & 32 & 64 \\
Positif & 18 & 36 \\
\hline \multicolumn{1}{c}{ Jumlah } & $\mathbf{5 0}$ & $\mathbf{1 0 0}$ \\
\hline
\end{tabular}

\begin{tabular}{lcc}
\hline Pendidikan & & \\
Rendah & 34 & 68 \\
Tinggi & 16 & 32 \\
\hline \multicolumn{1}{c}{ Jumlah } & $\mathbf{5 0}$ & $\mathbf{1 0 0}$ \\
\hline Dukungan & & \\
Keluarga & 30 & 60 \\
Tidak & 20 & 40 \\
Mendukung & & \\
Mendukung & & \\
\hline \multicolumn{1}{c}{ Jumlah } & $\mathbf{5 0}$ & $\mathbf{1 0 0}$ \\
\hline Pemberian & & \\
Imunisasi & 42 & 84 \\
HB-0 & 8 & 16 \\
Tidak & & \\
memberikan & & $\mathbf{1 0 0}$ \\
Memberikan & & \\
\hline \multicolumn{1}{c}{ Jumlah } & $\mathbf{5 0}$ &
\end{tabular}

Hasil uji bivariat dengan menggunakan uji chi-square untuk melihat hubungan variabel independen (pengetahuan, sikap, pendidikan, dukungan keluarga) terhadap variabel dependen (pemberian imunisasi Hepatitis B-0), diperoleh hasil dari 4 variabel yang diteliti terdapat 3 variabel yang berhubungan yaitu : pengetahuan ( $p$ value 0,000$)$, sikap ( $p$ value 0,000$)$ dan pendidikan ( $p$ value 0,000$)$. Sedangkan variabel dukungan keluarga menunjukkan tidak ada hubungan ( $p$ value 0,144$)$.

Tabel 2.

Faktor-faktor yang Berhubungan dengan Pemberian Imunisasi Hepatitis B-0 pada Ibu yang Memiliki Bayi di Puskesmas Bonai Darussalam

Kabupaten Rokan Hulu Tahun 2016

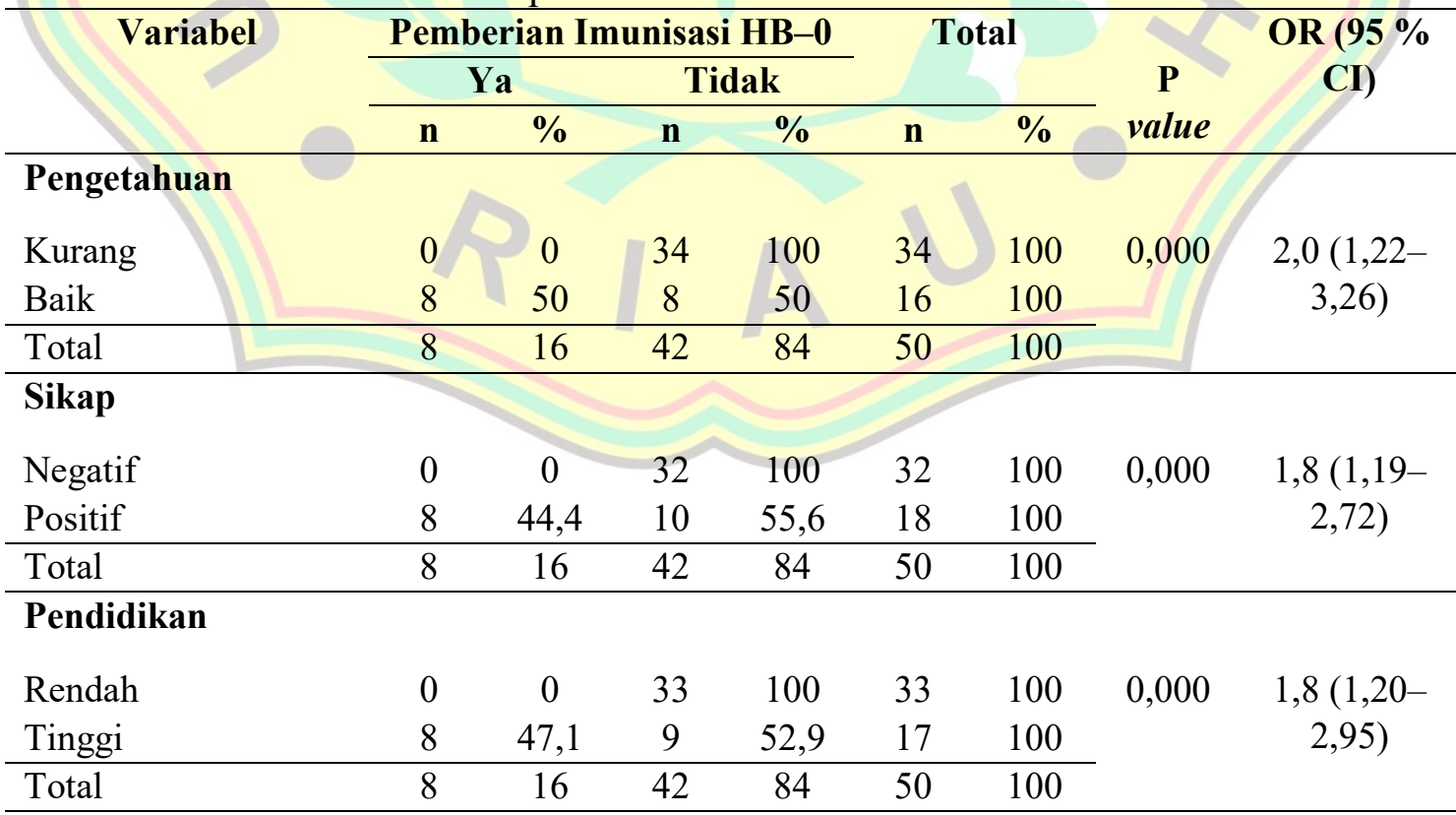




\begin{tabular}{|c|c|c|c|c|c|c|c|c|}
\hline \multirow[t]{3}{*}{ Variabel } & \multicolumn{4}{|c|}{ Pemberian Imunisasi HB-0 } & \multirow{2}{*}{\multicolumn{2}{|c|}{ Total }} & \multirow{3}{*}{$\begin{array}{c}\mathrm{P} \\
\text { value }\end{array}$} & \multirow{3}{*}{$\begin{array}{c}\text { OR }(95 \% \\
\text { CI) }\end{array}$} \\
\hline & \multicolumn{2}{|c|}{ Ya } & \multicolumn{2}{|c|}{ Tidak } & & & & \\
\hline & $\mathbf{n}$ & $\%$ & $\mathbf{n}$ & $\%$ & n & $\%$ & & \\
\hline \multicolumn{9}{|l|}{$\begin{array}{l}\text { Dukungan } \\
\text { Keluarga }\end{array}$} \\
\hline Tidak mendukung & 5 & 12,2 & 36 & 87,8 & 41 & 100 & \multirow[t]{3}{*}{0,144} & \multirow{3}{*}{$\begin{array}{c}3,6(1,67- \\
1,91)\end{array}$} \\
\hline Mendukung & 3 & 33,3 & 6 & 66,7 & 9 & 100 & & \\
\hline Total & 8 & 16 & 42 & 84 & 50 & 100 & & \\
\hline
\end{tabular}

Hubungan antara Pengetahuan dengan Pemberian Imunisasi Hepatitis B-0

Penelitian ini menunjukkan adanya hubungan yang bermakna antara pengetahuan dengan pemberian imunisasi $\mathrm{HB}-0$ dengan $\mathrm{P}$ value $=0,000$. Hasil OR didapat $=2,0(95 \% \mathrm{CI}$ $1,22-3,26)$ artinya ibu yang pengetahuannya kurang berisiko 2 kali tidak memberikan imunisasi HB-0 dibandingkan dengan ibu yang pengetahuan yang baik.

Menurut Notoatmodjo (2007), pengetahuan merupakan hasil dari tahu dan ini terjadi setelah orang melakukan penginderaan terhadap suatu objek tertentu dan merupakan domain yang sangat penting dalam membantu tindakan seseorang. Untuk memenuhi rasa ingin tahu tersebut dapat dipenuhi atau dicapai apabila ada pengetahuan tentang apa yang ingin diketahui. Seorang ibu bersedia bayinya diberikan imunisasi Hepatitis B-0 karena mengetahui manfaat dari imunisasi. Namun sebaliknya, kurangnya pengetahuan ibu tentang imuniasi Hepatitis B-0 menyebabkan ibu tidak memberikan imunisasi pada bayinya.

Sejalan dengan penelitian yang dilakukan oleh Jannah (2009) dengan judul Faktor-faktor yang Berhubungan dengan Status Imunisasi Dasar pada Balita Usia 12-23 Bulan di Wilayah Kerja Puskesmas Padarincang Kabupaten Serang, menyatakan bahwa ada hubungan antara pengetahuan dengan status imunisasi dasar dengan $\mathrm{P}$ value $=0,004$.

Menurut asumsi peneliti, banyaknya ibuibu yang tidak memberikan imunisasi HB- 0 di Puskesmas Bonai Darussalam Pasir Pangaraian Kabupaten Rokan Hulu dikarenakan kurangnya pengetahuan tentang imunisasi HB-0. Penyuluhan yang dilakukan oleh petugas kesehatan masih kurang dan ibu-ibu masih takut jika bayinya yang baru lahir sudah diberi imunisasi.

Hubungan antara Sikap dengan Pemberian Imunisasi Hepatitis B-0

Penelitian ini menunjukkan adanya hubungan yang bermakna antara sikap dengan pemberian imunisasi $\mathrm{HB}-0$ dengan $\mathrm{P}$ value $=$ 0,000 . Hasil OR didapat $=1,8(95 \%$ CI 1,19 2,72 ) artinya ibu yang sikapnya negatif berisiko 1,8 kali tidak memberikan imunisasi $\mathrm{HB}-0$ dibandingkan dengan ibu yang sikapnya positif.

Menurut Notoatmodjo (2007), sikap merupakan reaksi atau respon yang tertutup dari seseorang terhadap suatu stimulasi atau objek. Fungsi sikap belum merupakan tindakan (reaksi terbuka) atau aktivitas, akan tetapi merupakan predisposisi perilaku (tindakan) atau reaksi tertutup. Seorang ibu yang mengetahui bahwa imunisasi HB-0 penting untuk bayinya yang baru lahir akan membawa ibu untuk berfikir dan berusaha supaya bayinya tidak terkena penyakit yang disebabkan oleh Virus Hepatitis B. Dalam berfikir ini komponen emosi dan keyakinan ikut bekerja sehingga ibu tersebut berniat untuk membawa bayinya mendapatkan imunisasi HB- 0 .

Sejalan dengan penelitian yang dilakukan oleh Jannah (2009), menyatakan bahwa ada hubungan antara sikap dengan status imunisasi dasar dengan $\mathrm{P}$ value $=0,038$.

Menurut asumsi peneliti, banyaknya ibuibu yang tidak memberikan imunisasi $\mathrm{HB}-0$ di Puskesmas Bonai Darussalam Pasir Pangaraian Kabupaten Rokan Hulu dikarenakan kurangnya keyakinan dan ragu-ragu jika bayinya yang baru lahir sudah diberikan imunisasi. Hal ini juga didukung dengan pengetahuan ibu yang kurang tentang imunisasi. 
Hubungan antara Pendidikan dengan Pemberian Imunisasi Hepatitis B-0

Penelitian ini menunjukkan adanya hubungan yang bermakna antara pendidikan dengan pemberian imunisasi $\mathrm{HB}-0$ dengan $\mathrm{P}$ value $=0,000$. Hasil OR didapat $=1,8(95 \% \mathrm{CI}$ 1,20-2,95) artinya ibu yang berpendidikan rendah berisiko 1,8 kali tidak memberikan imunisasi HB- 0 dibandingkan dengan ibu yang berpendidikan tinggi.

Menurut Notoatmodjo (2007), pendidikan diperlukan untuk mendapatkan informasi, seperti berbagai hal yang menunjang kesehatan sehingga meningkatkan kualitas hidup. Makin tinggi tingkat pendidikan seseorang, makin mudah menerima informasi. Makin mudah seseorang menerima informasi, sehingga makin mudah pula menerima terhadap nilai-nilai yang baru dikembangkan. Seorang ibu bersedia bayinya diberikan imunisasi $\mathrm{HB}-0$ karena memahami bahwa imunisasi tersebut sangat penting diberikan. Pemahaman ini ditunjang oleh latar belakang pendidikan ibu.

Sejalan dengan penelitian yang dilakukan oleh Jannah (2009), menyatakan bahwa ada hubungan antara pendidikan dengan status imunisasi dasar dengan $\mathrm{P}$ value $=0,001$.

Menurut asumsi peneliti, banyaknya ibuibu yang tidak memberikan imunisasi HB-0 di Puskesmas Bonai Darussalam Pasir Pangaraian Kabupaten Rokan Hulu dikarenakan pendidikan yang masih rendah, rata-rata berpendidikan SD-SMP. Sehingga sulit bagi mereka untuk menerima informasi pentingnya imunisasi tersebut diberikan untuk bayi mereka.

\section{Hubungan antara Dukungan Keluarga dengan Pemberian Imunisasi Hepatitis B-0}

Penelitian ini menunjukkan tidak adanya hubungan antara pendidikan dengan pemberian imunisasi HB-0 dengan P value $=0,144$.

Menurut Achmadi (2006), pengaruh keluarga terhadap pembentukan sikap sangat besar karena keluarga merupakan orang yang paling dekat dengan anggota keluarga yang lain. Jika sikap keluarga terhadap imunisasi kurang begitu respon dan bersikap tidak menghiraukan atau bahkan pelaksanaan kegiatan imunisasi.
Maka pelaksanaan imunisasi tidak akan dilakukan oleh ibu bayi karena tidak ada dukungan oleh keluarga.

Berbeda dengan penelitian yang dilakukan oleh Jannah 2009), menyatakan bahwa ada hubungan antara dukungan keluarga dengan status imunisasi dasar dengan $\mathrm{P}$ value $=0,039$.

Menurut asumsi peneliti, tidak adanya hubungan antara dukungan keluarga dengan pemberian imunisasi HB-0 dikarenakan pada awalnya informasi ibu terhadap pentingnya pemberian imunisasi HB-0 sudah kurang yang juga didukung oleh faktor pendidikan dan sikap yang negatif. Sehingga dengan atau tanpa dukungan keluarga pun hal ini sudah memperkuat ibu tidak ingin bayinya diberikan imunisasi HB-0.

\section{KESIMPULAN DAN SARAN}

\subsection{Kesimpulan}

Berdasarkan hasil penelitian dan analisis data, maka dapat dismpulkan bahwa faktorfaktor yang berhubungan dengan pemberian imunisasi Hepatitis B-0 antara lain : pengetahuan ( $p$ value 0,000 dan OR 2 ), sikap ( $p$ value 0,000 dan OR 1,8$)$ dan pendidikan $(p$ value 0,000 dan OR 1,8).

\subsection{Saran}

Diharapkan bagi tenaga kesehatan Puskesmas Bonai Darussalam agar lebih meningkatkan kinerjanya dalam meningkatkan pengetahuan dengan cara penyuluhan kepada ibu-ibu yang memiliki bayi, bidan praktek swasta, dukun di wilayah kerjanya, dengan harapan ibu dapat termotivasi untuk memberikan imunisasi HB-0 pada bayinya.

\section{DAFTAR PUSTAKA}

Achmadi, U.F, 2006. Imunisasi Mengapa Perlu ?, Jakarta Penerbit Buku Kompas

Depkes RI, 2005. Pedoman Teknis Imunisasi Tingkat Puskesmas.

Depkes RI, 2013. Pedoman Penyelenggaraan Imunisasi.

Dinkes Kab Rokan Hulu, 2015. Data cakupan Imunisasi Hepatitis B-O 
Hidayat, B. \& Pujianto, P, 2008. Hepatitis B, Jakarta : Ikatan Dokter Anak Indonesia

Jannah. Faktor-faktor yang Berhubungan dengan Status Imunisasi Dasar pada Balita Usia 12-23 Bulan di Wilayah Kerja Puskesmas Padarincang Kabupaten Serang. Skripsi Program
Studi Ilmu Keperawatan Fakultas

Kedokteran Dan Ilmu Kesehatan Universitas Islam Negeri Syarif Hidayatullah Jakarta : 2009

Sugiyono, 2011. Metode Penelitian Pendidikan, Alfabeta.

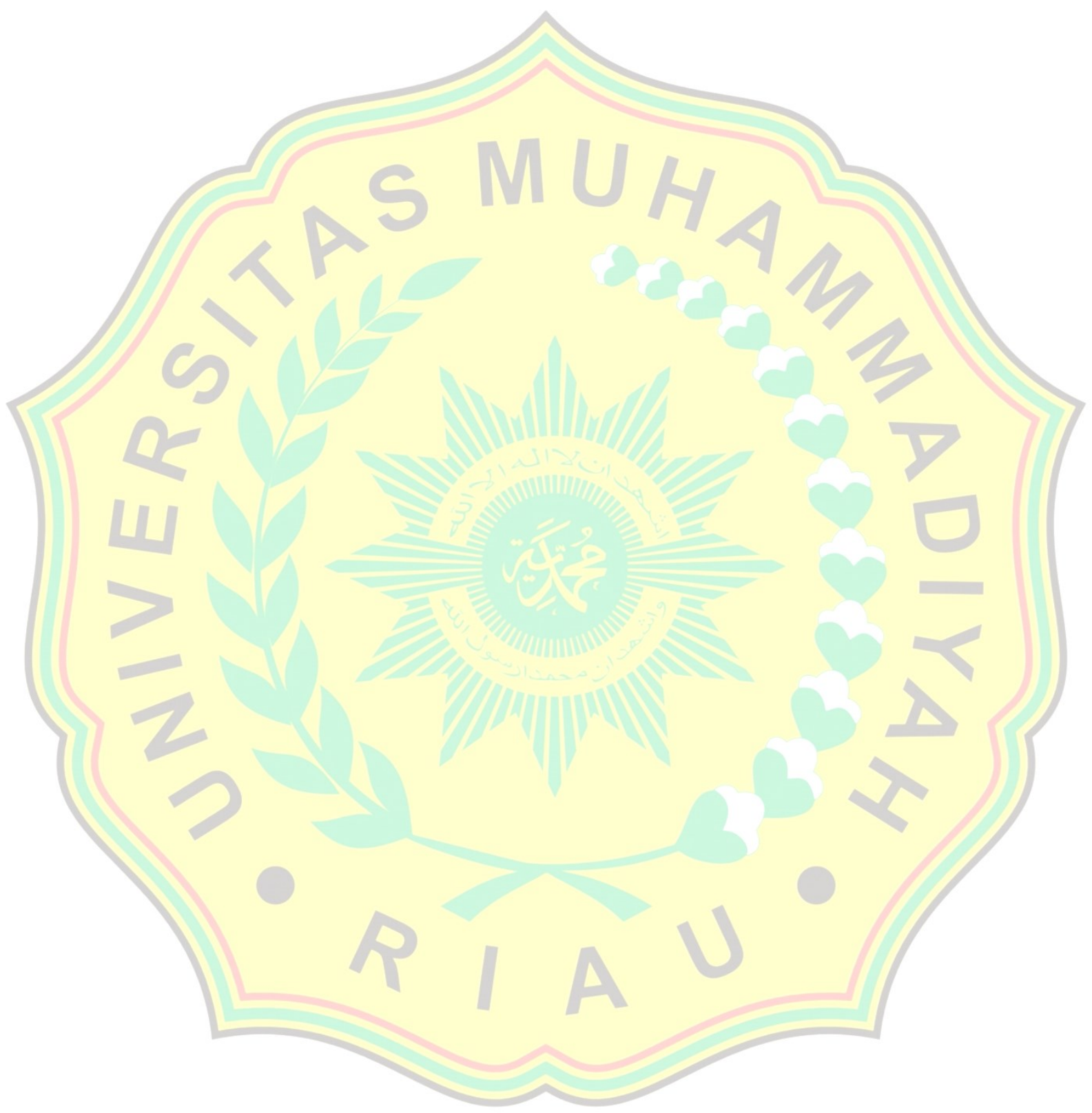

